821.163.41.09-31 Селенић С.

https://doi.org/10.18485/msc_pred.2018.7.ch10

Михајло ПАНТИЋ

Филолошки факултет

Универзитет у Београду

\title{
РОМАНИ СЛОБОДАНА СЕЛЕНИЋА У СРПСКОМ КЬИЖЕВНОИСТОРИЈСКОМ КОНТЕКСТУ
}

Мада у основним цртама, како књижевноисторијског тока тако и владајућег генеричког система, следи, понавља и развија све карактеристике своје шире европске породице, српску књижевност новога доба (18-19. и 20. век) одликује и низ специфичности. Тај моменат разлике почива, најпре, на разлици самог језика, јер сваки језик, сведочи нам искуство, образује посебан књижевноуметнички систем (идентичан у општој матрици генеративног процеса, али посебан управо у начину реализације), док је делом условљен и посебношћу, а у случају српске књижевности и поливалентношћу и дисконтинуираношћу њених историјских модела.

Посматрамо ли, на пример, српску књижевност из угла анализе њених жанровских својстава или генезе приповедних форми, а нарочито ако се усредсредимо на уметничку, фикцијску прозу, лако ћемо установити да у њој посебно видно и изузетно важно место има приповетка, укључујући ту све прозне облике краће од романа (цртица, кратка прича и новела), потом приповест, прелазну форму између приповетке и кратког романа, и, коначно, приповедни венаи, нарочит вид структурације мањих наративних целина, помоћу којег се и отвара романескни хоризонт („циклизацијом новела" се у наратологији тумачи и генеза романа). Сасвим прецизна теоријска разликовања побројаних кратких наративних форми с временом је релативизовала књижевна пракса, која је, почев од романтизма наовамо, склона интензивној жанровској комбинаторици, а не репродуковању истоврсних, теоријски нормираних наративних структура.

Прозни облици и жанрови данас једва да постоје у чистом виду; у сваком случају, јављају се и укрштају на друкчији начин него некад. Ипак, први критеријум њиховог теоријског разликовања остао је непромењен, 
и по природи је и даље постојано квантитативан. Прозне жанрове одувек разликујемо по категоријима дужине, односно, краткоће, па је темељно својство сваког европског прозног система од Дон Kuхота до наших дана разлика између романа и приповетке. Роман тотализује слику света, он тежи интегралности и обухватности приказаних предметности (и при том апсорбује све друге књижевне родове и врсте, а у модерним временима интензивно се проширује и на „некњижевност”, упија документа, мемоаре и све друге нефикционалне облике), док се приповетка усредсређује на „ограничени свет”, на помно дочаран детаљ, карактер, кључну ситуацију. Роман, потом, почива на конвенцији текстуалности, он такорећи увек почиње од неког текста (текста схваћеног у најширем значењу те речи, као меморисаног и записаног трага културе; у том смислу, и мит је текст, и историја је текст, и пронађени документ је текст, и мишљење је текст), и у тексту завршава. Роман реартикулише и „отекстовљује” знање и имагинацију, даје им облик, помаже им да дођу до свести о себи. Он, то говори књижевно искуство, не може настати изван писане културе, изван библиотеке. Роман је и апсорпција и екстензија, како год да разумемо те апстрактне категорије. Он у новим временима долази на друштвено и уметнички повлашћено место које је у старије доба заузимао еп, а обе те велике форме само су појавни облици митског мишљења. Мит, схваћен као прича, основ је сваке прозне књижевности.

Без развијене грађанске културе, без претходно формиране традиције жанра, грађевина српског романа подиже се споро и спорадично (Милован Видаковић, Јован Стерија Поповић, Богобој Атанацковић, Јаков Игњатовић), док приповетка спонтано израста из дубоког тла усменог памћења, из изворног (пра)облика. Роман ће преузети пуну иницијативу тек у другој половини 20. века, када српска књижевност и култура у потпуности овладају поетичким кодовима симултаних европских књижевних процеса, док су и најбољи српски романи у реализму засновани на проширивању анегдоте, приче и приповетке, па је чак и жанровска ознака коју писци употребљавају за та своја дела (Стеван Сремац, на пример) управо: - приповетка, а они репрезентативни за раздобље модерне и првог модернизма (Станковић, Црњански) више знак снаге индивидуалног талента него израз потпуне физиогноматске и поетичке довршености српског романописања.

Док развијене европске књижевности у 19. веку добијају своје романсијере-класике (Балзак, Флобер, Достојевски, Толстој), ауторе парадигматичних, темељних романескних остварења у којима цивилизација и култура долазе до најдубљих стваралачких и мисаоних самоувида, српски романсијери, чак и они најбољи (Јаков Игњатовић, пре свих), још се паште око неких техничких питања романописања, еволутивном нужношћу присиљени да у својим делима, али први пут на српском језику, понављају у Европи већ одавно пређене еволутивне етапе најсложеније 
и најобимније прозне форме. Хагиографска традиција српске средњовековне књижевности, боље рећи, поетичка, друштвена и естетичка основа те традиције, сувише су далеко од српских романописаца 19. века да би они у њој могли пронаћи истински креативни подстицај, а Видаковићеви романескни покушаји са почетка тога столећа наивни су и анахрони. Сећање на бивши тип текстуалности после Вукове реформе сасвим је избледело, заувек је промењена језичка норма, а са њом и модел националне културе, али је, показује се у самој књижевној пракси, у текстовима који у њој настају, нови (грађански) друштвени модел у Србији средином 19. века још неразвијен да би се могао, на потпуно остварен начин, естетски упечатљиво рефлектовати кроз индивидуални таленат чак и најбољих романсијера. Роман, дакле, тада још није развијен јер ништа око њега није довољно развијено. За роман треба и даха, и грађе, и ерудиције, и институционализовано формулисане културе, и систематичног образовања, и временске дистанце и, наравно, дара који није само примаран (какав је, претежно, дар песника и приповедача), већ захтева и непрестану проверу и непрестану култивацију унутар високоразвијеног, грађанског културног контекста, будући да роман и друштво, функционишу по принципу спојених судова: друштво иште роман да би се у њему огледнуло и да би, путевима имагинације и спекулације, дошло до истине о себи, а роман, напросто, без таквога друштва није могућ.

У 20. веку мења се структура књижевног система. Са развојем друштва и са вишеструком институционализацијом саме књижевне уметности, роман добија по свему повлашћено, доминантно место. Крајем прве деценије века (1910) излази први модерни српски роман, Нечиста крв Боре Станковића, а у међуратном раздобљу издвајају се, већ по свему упоредиви са европским књижевним контекстом, романи писаца првог модернизма (Драгиша Васић, Милош Црњански, Растко Петровић, итд.). Књижевно време после другог светског рата обележила је појава романа Иве Андрића (На Дрини ћуприја, Травничка хроника, Госпођица, сви 1945; потом и Проклета авлија, 1953), а током 50-их година уследила је појава романа писаца другог модернизма (Бранко Ћопић, Добрица Ћосић, Оскар Давичо, Михаило Лалић). Некада високо вредновани, ти романи, данас, сагласно промени књижевног и поетичког контекста, захтевају нова читања и ревалоризацију. Током исте деценије јављају се и романсијери експерименталније оријентације, у сагласју са симултаном приповедном праксом европске књижевности (Радомир Константиновић, Павле Угринов, Бора Ћосић), али ни та дела нису очувала читљивост изван академских кругова, па је у савременом добу њихов значај превасходно књижевноисторијски и историјскопоетички, јер су у српску књижевност унели нова приповедна решења и проширили могућности наративног израза. Уз Андрићеву Проклету авлију уметнички најуспелије романе у тој деценији објавио је 
Владан Десница (Зимско љетовање, 1950; Прољећа Ивана Галеба, 1957). Други модернизам прати противречна рецепција, у распону од критичке адорације до потпуног ниподаштавања, са недвосмисленим идеолошким предзнаком. Иако су протагонисти књижевних спорова, готово без изузетка, чланови Комунистичке партије, међу њима се јавља раслојавање на „реалисте” и „модернисте”, окупљене око концепцијски супротстављених часописа Савременик и Дело. Та полемика ће, попут низа ранијих, а и каснијих сукоба мишљења у српској књижевности и око ње, у великој мери обележити укупну стваралачку климу онога доба.

Током 60-их година 20. века постепено се у српској књижевности обликују нове поетичке конфигурације, и јављају се нова списатељска имена, а класици достижу стваралачки зенит. Милош Црњански објавио је велики роман Сеобе, књига друга (1962), једну од најзначајнијих књига модерне српске књижевности, и хибридну прозу Код Хиперборејаца (1966), а Меша Селимовић такође један од најзначајнијих српских романа свих времена - Дервиш и смрт (1966). У тој деценији прве књиге публикују и писци високог модернизма Александар Тишма, Данило Киш, Борислав Пекић и Милорад Павић, напоредо негујући типове критичке, демаскирајуће и алегоријско-фантастичне, ерудитне, немиметичне прозе. Поткрај 60-их година долази до снажне обнове реализма и неонатурализма, јавља се проза „црног таласа” (Драгослав Михаиловић, Слободан Селенић, Живојин Павловић, Видосав Стевановић, Милисав Савић, Мирослав Јосић Вишњић итд.). Као и другде у Европи, мада са извесним закашњењем које може бити тумачено на више начина, роман и у Србији током 20. столећа постаје доминантна књижевна врста, односно репрезентативни текст епохе - општа друштвена кретања, али и судбина појединца у вртлогу тих кретања, почињу у роману да добијају своју приповедну, књижевноуметничку форму и слику. Анализа и коментар опште и личне судбине попримају свој фикционални, симболички и алегоријски облик, па се из описаног књижевноисторијског контекста може извући закључак да је српски роман радом креативних појединаца у историјском процесу промене књижевне имагинације поступно успостављен као специфична, паралелна повест друштвених збивања, односно да се у нашем добу, на многим ваљаним примерима указује као добро установљен, репрезентативан уметнички начин да се, у форми приповедне, прозне фикције, обликује, представи и разуме све оно што време са собом носи.

Управо у таквом контексту раста и развоја модерног српског романа незаобилазно је име Слободана Селенића (1933-1995), писца посвећеног ослушкивању и уочавању оних понекад бруталних, понекад невидљивих, а понекад и перфидних друштвених механизама који обликују људски живот и, више од тога, одређују му судбину, најчешће са трагичним исходом. Селенић се најпре афирмисао као позоришни критичар и теоретичар 
драме, да би у зрелим годинама, са акумулираним животним искуством, слично као и његов генерацијски друг и сапутник Борислав Пекић, такође велики романсијер, дебитовао врло примећеним и врло читаним романом Мемоари Пере Богаља (1968). Потом је уследила дужа пауза, не зато што писац није писао, него стога што је његов роман Писмо глава био „на леду”, то јест, није штампан због цензорски неприхватљиве, трауматичне, „табу-теме” сукоба унутар југословенског комунистичког режима (1948, Голи оток, егзекуције неистомишљеника). Тај роман објављен је тек 1982. године, а након што је Слободан Селенић за свој трећи по реду написан, а други по реду објављен роман Пријатељи (1980) добио тада најпрестижнију југословенску, а данас српску награду за роман године, коју од 1954. до данас додељује недељник НИН. Са та три романа Селенић стекао је репутацију једног од најчитанијих савремених српских прозних писаца, да би са наредним романима Очеви и оци (1985), Timor mortis (1989) и његов књижевни рејтинг настављао да расте. Последњи за живота објављен Селенићев роман Убиство с предумишљајем (1993), премда не и естетски најуспелији, захваљујући актуелности теме (туробно искуство грађанског рата у којем се распала друга Југославија) и чињеници да је по њему снимљен врло гледан истоимени филм (1995, режија Горчин Стојановић) постао је бестселер. У Селенићевој заоставштини је нађен и недовршен роман Малајско лудило (објављен 2003), којим је још једном потврђено да се кључна тематска преокупација његових дела по правилу своди на приповедно предочавање и обликовање трауматичних збивања из друге половине 20. века, а управо таквим историја балканског поднебља обилује преко сваке мере.

Није тешко одгонетнути због чега је Селенић постао омиљен и радо читан писац чије се књиге и данас штампају у тиражима пре карактеристичним за популарну и тривијалну, него за прворазредну уметничку књижевност, каква Селенићева свакако јесте. У времену које је снажно релативизовало, па и потценило значај романескне приче, Слободан Селенић је остао веран старом уверењу да је пишчева обавеза да занимљиво и питко приповеда о теми која је већ по себи занимљива за многе од његових савременика, јер се свих њих и непосредно, искуствено тиче. Управо следом таквог уверења Селенић је, заједно са својим тематски блиским сапутницима, већ поменутим Бориславом Пекићем и најчитанијом савременом српском списатељицом Светланом Велмар Јанковић, у свим својим романима приповедао велику причу о сумраку српске грађанске класе, о трајној нерегуларности и трауматичности услова у којима је живело српско друштво, настојећи да се током целог минулог столећа у потпуности европеизује. Слободан Селенић је у том смислу сведок једне епохе, и њен надахнути тумач, а то сведочанство и то тумачење, захваљујући високом нивоу уметничке реализације, могу са лакоћом да разумеју и да прихвате 
и читаоци који говоре другим језицима и живе у другим, у понечему ипак блиским земљама. Јер је и сама историја европске грађанске класе у ствари велики филм пун трагичних епизода, свеједно да ли читамо Балзака, Толстоја, Голдсвортија или Томаса Мана. Дух европског грађанског приповедања је свуда исти, макар начини реализације били увек различити, како у врхунској прозној уметности уосталом и треба да буде.

Читљивост и висока читаност свих Селенићевих романа, која после његовог коначног одласка, како је већ речено, не опада него расте, показују, између осталог, да је писац у нечему погодио. Погодио је у чињеници коју је непрестано описивао, испитујући безбројно мноштво њених видова: да на разлици почива свет, да разлика тај свет покреће и да разлика индукује лице света. Писац Селенић зна за неуралгичност чињенице да разлике природно теже да опстану и да се афирмишу, али да их историја, идеологија, политика, идолатријска митологија, па и примењена, скучена етика, непрестано укидају, да их ниште и потиру, чим мало више промоле главу. И о томе углавном и приповеда у својим романима, готово грозничаво настојећи да продре у саму бит различитости, покушавајући да разуме како и зашто ,ја” види „друго” и како „друго” види , ја”, и, више од тога, како и зашто „ми” видимо „њих”, а како „они” виде „нас”, и све се претвара у колоплет најразличитијих перспектива, у „рашомонијаду” која негира постојање арбитрарног и ауторитарног центра - свет непрестано измиче, јер је у свом бићу различит. Иманентна различитост манифестује се у образинама и фигурама секундарних различитости, друштвени живот је нека врста карневала без маски, нико не потенцира различитост, али је она напросто очевидна. Разлика остаје, она је корен остварености али и усуда.

У нееманципованим друштвима, каква су, на пример, сва идеолошка, различитост се разрешава несрећом и трагедијом, док се, утопијски посматрано, будући да стварна историја не бележи такве случајеве, различитост и прихватање другости може узети за потенцијални извор среће живљења. Као дете свога времена, као интелектуалац формиран у добу које је затомњивало разлике, као писац који је, према хуманистичком диктуму, веровао да књижевност може барем мало кориговати свет и дати му минимум етичког дигнитета, као сведок и тумач прераног сумрака српске грађанске класе, као критичар заинтересован за питања форме и ангажмана, сасвим прецизно, његовим речима, за Ангажман у драмској форми (како гласи наслов његове књиге из 1965), као писац који се прошавши кроз експериментална искуства уметничке праксе 50-их и 60-их година 20. века промишљено определио за „средњи пут”, Слободан Селенић је нашао неку своју, препознатљиву меру, која се у контексту српске прозе, а напосе романа последње трећине тога века, најпре чита у кључу стабилног, готово основног, нормативног обрасца, једног реалистичком традицијом успостављеног, а модернистичким ретушом довршеног, разложно нађе- 
ног прозног облика. Ништа код Селенића не привлачи на први поглед: у српској књижевности његовог времена било је већих мајстора форме, надахнутијих иноватора, дубљих аналитичара, бескомпромиснијих детабуиста, сугестивнијих приказивача људског усуда и патње, радикалнијих критичара идеологије, а нарочито језички много понесенијих и богатијих писаца, али, када се све сабере, излази да писаца какав је Слободан Селенић модерна српска књижевност нема превише. Селенић је умео да влада формом и да конструктивно поштује конвенције, знао је да одабере и постави тему, да истакне њен значај и да је учини вредном приповедања, те, можда на првом месту, да је опредмети судбином ликова са којима се читалац, зарад њихове уверљивости, одмах идентификује. Не заборавимо да је идентификација одувек па и данас први разлог због којег уопште и читамо фикционалне текстове.

За четврт века, колико се бавио прозним радом, Слободан Селенић је написао шест романа различите уметничке вредности, али све од реда значајне, ниједан испод црте, и започео седми, судећи по објављеним фрагментима, такође занимљив и такође окренут питањима разлика и различитости. Значај неког писца мери се на различите начине, неки од њих плене ширином и обиљем опуса, неки изузетношћу једног јединог дела. Слободан Селенић не престаје да нас заокупља уметнички овладаном формом грађанског романа, оног романа који из критичке перпсективе посматра неуралгичну друштвену стварност. У тој форми романа питање етике налази се у корелацији са питањима естетике: етички проблем мора се на неки начин превазићи, превладати, а процес тога превазилажења мора породити и одређени естетички ефекат, ефекат прочишћења. Све нас то, наравно, подсећа на нека од кључних питања поетике зачета још у античко доба, а изнова постављена и у модерним временима.

Селенићеви романи јесу одговор једног проницљивог и надахнутог писца на та, кључна егзистенцијална питања. 